\title{
A Brief Prehistory of Philosophical Paraconsistency
}

\author{
William H. F. Altman \\ Universidade Federal de Santa Catarina
}

\begin{abstract}
In celebration of Newton da Costa's place in the history of paraconsistency, this paper considers the use and abuse of deliberate self-contradiction. Beginning with Parmenides, developed by Plato, and continued by Cicero, an ancient philosophical tradition used deliberately paraconsistent discourses to reveal the truth. In modern times, decisionism has used deliberate self-contradiction against Judeo-Christian revelation.
\end{abstract}

Keywords: Paraconsistency, Parmenides, Plato, Cicero, decisionism, and Leo Strauss.

In "Remarks about Quantum Ontology," Décio Krause (2000: 156) mentions a story about an invisible lion used by G. Toraldo di Francia to explain the complicated relationship between the physicist and "microscopic objects." The presence of circling condors indicated to the guide (a) the presence of a tasty meal (in this case, the carcass of a horse) (b) the absence any possibility for those high-flying condors to partake of this meal, hence the simultaneous presence (c) of an invisible lion, enjoying the horse at her or his leisure but unwilling to share it with any mere birds. In the Pampas, where this story is set, it was theoretically possible to actually find the lion; hence the guide's otherwise mysterious response to the condors-"A lion!"- could be verified in practice and its object identified as itself. In the quantum world, however, we are dealing with what Krause calls "the idea of indistinguishable quanta" (p. 157). Like the guide, our instruments may indicate the presence of "a lion." But as a matter of both practice and theory, there is no way to identify this particular kind of "object" as itself. As a matter of principle, then, the guide's counter-factual assertion-for all intents and purposes, he was identifying the circling condors as a lion-is analogous to the closest we can get: in the absence of the possibility of identifying the lion, the circling condors both are and are not the missing object or rather its "idea."

Consider this story in reverse, from the lion's perspective. Suppose the lion to be eager to reveal her or his presence to the travelers but also aware, as a matter of both theory and practice, that there is no possibility of becoming an identifiable object for them due to their own epistemological limitations. Unable to grasp the idea of "lion," the travelers were nonetheless capable of grasping both "dead horse" and "feasting condors." The travelers were therefore taught that wherever there was the first, there were also the second. Furthermore, let us suppose this to be defined

Principia 14(1): 1-14 (2010).

Published by NEL — Epistemology and Logic Research Group, Federal University of Santa Catarina (UFSC), Brazil. 
for them as a matter of logic and definition: DH $\supset$ FC or even $\neg$ (DH \& $\neg$ FC). So when, in visible proximity to a tasty dead horse (DH), the travelers could see the condors keeping an otherwise inexplicable distance $(\neg \mathrm{FC})$, it might be possible for the invisible lion (IL) to reveal her- or himself precisely in that mysterious distance. Hence the system-exploding proposition: (DH \& $\neg \mathrm{FC}$ ) $\supset$ IL. If it is the logical system itself that makes it impossible to "see" the IL, then it is not, of course, any given absurdity that can be derived from a statement (e.g. DH \& $\neg \mathrm{FC}$ ) that violates the system-defining axiom $\neg(\mathrm{DH} \& \neg \mathrm{FC})$ or even (by extension) $\neg(A \& \neg A)$.

This meditation on deliberate or voluntary paraconsistency-we must imagine the lion as teaching an axiom inconsistent with his or her own existence-arises from the following passage in Krause's article (emphasis mine), a passage which immediately caught the eye of this Platonist.

The possibility of looking at the lion acts as the possibility of ostensively naming it, providing it with a label: that lion, lion $a$. But, as shown by M. Redhead and P. Teller, who have explored a cluster of problems concerning the Hilbert space formalism (first quantized approach), the consideration of names, or labels in quantum mechanics cause problems with regard to the idea of indistinguishable quanta. (Krause 2000: 157)

I would like to suggest that paraconsistency-so useful in finding ways to describe QM-has a venerable "prehistory" in Platonism: for Plato, the analogue of "IL" was, for example, "the Idea of the Justice." Inaccessible to our "instruments," the strictly intelligible Idea was at once (a) "the singular thing" that Plato wished to teach and (b) completely inexpressible except through indirection. In fact, just as I have insisted that "the lion" could be either male or female, so too Plato is determined not to commit himself even to identifying the Idea of Justice as "the" Idea as opposed to a quanta of "them." In other words, I propose (a) to take Krause's no doubt un-Platonic use of the Platonic word "idea" literally, and (b) to explore the inconsistency-based on the ancient problem of the One and the Many-involved in writing "the idea [singular] of indistinguishable quanta [plural]." In doing so, my purpose is best understood as identical with Krause's: just as he was intent on honoring Newton da Costa "on the Occasion of his Seventieth Birthday," so too I am writing "A Brief Prehistory of Philosophical Paraconsistency" on the occasion of this great man's eightieth. Philosophers can safely ignore a decade while attending to the timeless.

As opposed to "The History of Philosophical Paraconsistency," da Costa himself plays no part in its Prehistory: he may be both old and wise but he's not that old. As Henry Kyburg wrote in 1998:

Much of the driving force behind research into paraconsistent logic stems from da Costa, who, together with a number of others, has been publishing a steady stream of papers about paraconsistent logic ... There are, of course,

Principia 14(1): 1-14 (2010). 
other contradiction-tolerant logics ... But the earliest and most influential writings in this area are those of da Costa and his students and colleagues. They are worth attending to. (Kyburg 1998: 1183-4)

As a matter of definition, I would like to suggest that paraconsistency's prehistory excludes da Costa from consideration not only on chronological grounds, i.e. not solely because he is himself its history. Some indications of where I draw the line between paraconsistency's history and its prehistory are already to be found (a) in my reversal of the lion story, whereby the traveler became the pedagogical object as opposed to the exploring subject (and therefore analogous to the physicist) and (b) my reference to "deliberate or voluntary paraconsistency." While there is no doubt that da Costa's conception of paraconsistency is divisible from any objective physical problems that indicate its usefulness, my conception of paraconsistency's prehistory is that it has very little to do with what is true about the world, whether on the macro- or microscopic level, but most everything to do with discourses about, as it were, "the idea of indistinguishable quanta."

To put it another way: ancient or prehistoric paraconsistency does not arise from attempting to speak more meaningfully about events in the physical world that defy traditional logic: much the opposite. As defined here, "prehistoric paraconsistency" was predicated on the impossibility of doing so. From a Platonist's perspective, the modern problems arising from "Identity in Physics," particularly Quantum Mechanics (French and Krause 2006), are therefore hardly new: they were, albeit in a far more primitive form, the condition for the possibility of creating a new kind of discourse that deliberately made use of paraconsistency for a pedagogical purpose. Since (a) speaking the truth about the physical world was impossible, and (b) the mass of men, failing to recognize this fact, could only conceive of the truth in physical terms, (c) a new kind of discourse, inconsistent with what the mass of men could readily conceive, was required to reveal the invisible "idea." The use of the word "new" should not deter philosophers from applying it to Plato's teacher, "the great Parmenides."

Before presenting seven principles of paraconsistency's prehistory and structuring my brief account around them, I would like to flesh out the connection between my reversal of the lion story and Plato's deliberate pedagogical paraconsistency. In his Republic, Plato is intent on teaching his students "the Idea of Justice" and the closest he comes to allowing us to "see" this Idea is a parable of the unseen: the Allegory of the Cave in Book VII. "I went down" are the first words that Socrates says at the beginning of Book I; in the context of the Cave, it is obvious (Republic VII 517a6) that the philosopher who returns to it will suffer-as Glaucon indicates that he will suffer as a matter of theory in Book II (II 361e3-362a3) and that Socrates suffers as a matter of fact when he drinks the hemlock in B.C. 399-the penalty imposed on a just man who nevertheless appears to be unjust. Except in what his Socrates 
actually does-i.e. "I went down to the Piraeus with Glaucon, son of Ariston" (Republic I 327a1)-there is no explicit statement in Plato's Republic that the Idea of Justice is that which persuades the philosopher to voluntarily enter the deadly Cave of political life: much the opposite. Plato's Socrates instead teaches that justice in the city is a matter of each man doing the one job for which he is by nature suited (Republic IV 433a1-b4) and that justice in the individual is in no way dependent on any external action but rather on the harmonious operation of the individual's internal spiritual arrangements (Republic IV 443c9-444a2). In short: the definitions of justice in man and individual in Book IV negate the lion that Plato wishes those who travel through his literary universe to discover for themselves. His reasons for wishing or rather requiring them to do so, by the way, are revealed in Meno: true learning is recollection.

The justice of the city that Socrates reveals in Book IV follows directly from-is indeed identical to-an axiom he lays down in Book II (cf. Republic IV 433a5 and II $369 \mathrm{e} 2-370 \mathrm{~b} 6)$. The applicability of what he finds in the city to that which they seek in the individual is asserted in Book II (Republic II 368e2-369a4). The transference of the discovery made in the city to the individual man is made possible by another axiom laid down in Book IV: the Law of Non-contradiction makes its literary debut precisely here (Republic IV 436b8-437a9). But Socrates has already warned us about making this transfer at IV 434d6-435a3:

\begin{abstract}
But now let us work out the inquiry in which we supposed that, if we found some larger thing that contained justice and viewed it there, we should more easily discover its nature in the individual man. And we agreed that this larger thing is the city, and so we constructed the best city in our power, well knowing that in the good city it would of course be found. What, then, we

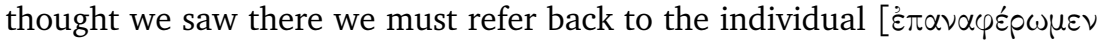

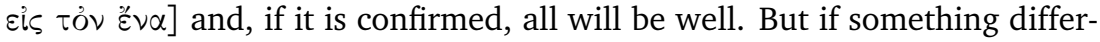
ent manifests itself in the individual, we will return again to the state and

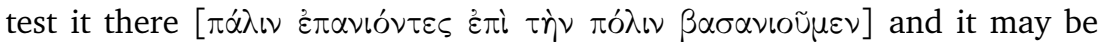
that, by examining them side by side and rubbing them against one another

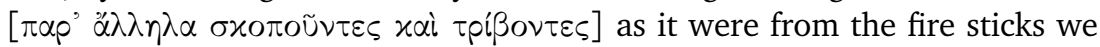

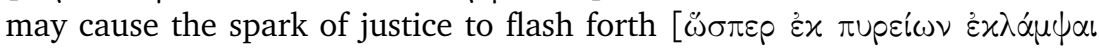

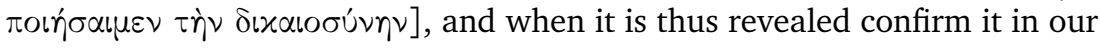
own minds.
\end{abstract}

This crucial text indicates that Plato has deliberately created in his Republic a paraconsistent discourse in which what the reader originally thought was true is in fact nothing more than one of two propositions-the other proposition contradicts itthat together will reveal what justice actually is. The second hint, quickly following this poetic prediction of dialectical friction, that the Book IV account of justice is or rather will be inadequate, is Socrates' reference to "a longer and harder way" that 
would lead to more accurate results (Republic IV 435c9-d5); in Book VI, looking back on the decision to take merely the shortcut that they did in Book IV, he further notes that a measure that falls short of accuracy "is no measure at all" (Republic VI 504c2-3).

It is only at the end of Book VI, however, on the verge of introducing the Cave at the start of Book VII, that Socrates reveals the methodological basis for the deliberate inadequacy of the justices (i.e. in both city and man) revealed in Book IV: in the Divided Line (Republic VI 509d6-511e5), Socrates provides us with sufficient evidence to discover for ourselves that those definitions rest on unexamined hypotheses and depend on visual images (VI 510b4-511a8). He states that only by rising above our axiom system can we reach the un-hypothetical starting point, working our way down from which, we arrive at the truth (Republic VI 511b3-c2). It is only then that Socrates tells the traveler about a philosopher who, having risen up to catch sight of the Idea of the Good, voluntarily albeit inexplicably goes back down into the Cave (Republic VII 516e3-4). But he quickly reverts to concealing the Idea of Justice by insisting that in the City that they have been constructing-merely the inevitable "visual image" for those who have understood the Divided Line-the philosophers will be compelled to participate in politics (Republic VII 519c8-520b4).

In short, the explicit definition of justice- "each man doing the one job for which he is by nature suited"-although impeccably derived from a well-defined axiom system, turns out to be exactly the opposite of Plato's teaching (cf. Republic V 473c11-e2 and VII 520e1): true justice is instantiated only when the philosopher-who detests politics and yearns to soar among unseen and indeed invisible realities (Republic V 475e3-4 and VII 519c1-d4)-voluntarily performs a second job by returning to the Cave. As opposed to the well-behaved justices of Book IV $\left(J^{\circ}\right)$-for this form of expression, see da Costa and Wolf 1980: 198-Plato has revealed the lion's presence only through the anomalous actions of the circling condors. Expressed less poetically, Plato provokes the reader to discover the truth principally by revealing the methodological inadequacy of that which contradicts the truth: he deliberately creates a paraconsistent universe containing $J \& J^{\circ}$ where $J$ is precisely the opposite of the axiom-based but deliberately inadequate $J^{\circ}$ and in which $J^{\circ}$ is made explicit while $J$ is only hinted not least of all because $J^{\circ}$ contradicts it, a circumstance that compels the reader to think beyond $\neg\left(J \& \neg J^{\circ}\right)$. Plato achieves this dialectical result by having his Socrates show us that what makes $J^{\circ}$ well-behaved is precisely that which simultaneously makes it sub-philosophical; ${ }^{1}$ by juxtaposing this with a more adequate method, he creates the condition for the possibility of the reader to not so much see as to become, as it were, "that lion, lion $a$," i.e. the instantiation or rather the imitator of "the Idea of Justice." With this introduction in place, I will now introduce the first of seven principles informing this brief prehistory of philosophical paraconsistency:

Principia 14(1): 1-14 (2010). 
1. If we wish to speak the Absolute Truth about the things of this world, we will fall into involuntary paraconsistency.

This principle has two aspects, i.e. it belongs both to paraconsistency's history and to its prehistory. As merely the historian of paraconsistency's prehistory, it is not incumbent upon me to explain how or even to assert that "the history of paraconsistency" begins with a response to the failed attempt to speak consistently about certain physical phenomena that do not conform to traditional or dogmatic logical systems; i.e. the attempt to formulate a discourse consistent with the paraconsistent phenomena. Therefore I will say nothing more about this, leaving that task to those far wiser than me.

"The prehistory of paraconsistency," by contrast, begins much earlier, before the invention of "traditional or dogmatic logical systems." In the prehistoric world of philosophical paraconsistency, Heraclitus is the crucial figure for proving the truth of this principle although its truth was probably already implicit in the attempt of the Presocratics generally to say what one thing (singular) all things (plural) are. As a matter of grammar, we can subvert the problem of the One and the Many by pointing out that in classical Greek, neuter plural subjects always take singular verbs: it is grammatical to say, for instance: "The trees is in the plain." And as a matter of scientific exposition, we can dodge the bullet with an expression like: "The single basis of all things is water."

But in Heraclitus, particularly because he was so intent on deliberately stating, as it were, "an indefinite quanta" of paraconsistent truths about the world, the problem became acute and led him to involuntary self-contradiction. In other words, Heraclitus is probably safe, as a matter of grammar and scientific exposition, when he claims: "All things flows" (Cratylus 402a) because the flux doctrine certainly annihilates the trans-temporal identity of any individual thing and may well undermine its numerical identity at any given moment as well; ${ }^{2}$ presumably Heraclitus would therefore have denied the Principle of Identity just as Aristotle says that his followers denied non-contradiction. As the reader will remember, Aristotle's challenge to any given Heraclitean in Metaphysics IV (1006a13) was: "Let him just say anything." As if in response, Heraclitus had already pretended that it is not he himself who says the most important thing: "Listening not to me but to the LOGOS, it is wise to agree that all things are one" (Diels-Kranz, fragment 50). By stating the truth in indirect discourse, the singular verb "it is" becomes the infinitive: "it is wise" (the only finite verb) "to agree" (the first infinitive) "all things" (neuter plural) "to be" (the second infinitive) "one." Greek grammar not withstanding, Heraclitus could not and therefore did not say: "all things is one." But that's exactly what he thought. Further proof of his involuntary paraconsistency is the preface to his self-contradictory piece of wisdom: are we hearing it from Heraclitus or the LOGOS? Of course it is the latter: 
Heraclitus is telling us what the LOGOS teaches. Such involuntary paraconsistency is not confined to the West: "The Tao that can be told is not the Tao;" so begins the Tao te Ching of Lao Tzu. What then are we being told? When one is attached to the Absolute Truth of paraconsistency, when one's account of the whole is based throughout on an all-pervasive paraconsistency, one will end up contradicting oneself involuntarily. The Tao is being told, it is always Heraclitus who speaks for the LOGOS, and "All things is One." Except that they aren't and can't be.

2. If we wish to avoid falling into involuntary paraconsistency, we would be well advised not to attempt speaking the Absolute Truth about the things of this world.

The denial of this principle is precisely the condition for the possibility of the history, as opposed to the mere prehistory, of paraconsistency. When Aristotle set himself to give a true account of all things based explicitly on non-contradiction and implicitly on the principle of identity throughout, he set in motion-by creating what appears to be the first among "traditional or dogmatic logical systems" - the process that eventually led to what might be called "the paraconsistent revolt." I take it that "the history of paraconsistency" is precisely the history of a revolt against a hegemonic or dogmatic (da Costa 1980) logical system that leaves no room for (1) any denial of Non-contradiction and/or (2) the merely partial validity or usefulness of Identity. To use da Costa's terms, dogmatic logic makes no room for "dialectical logic." Whether promulgated by Heraclitus or Zeno, paraconsistencies will therefore disappear in Aristotle.

As far as the Stagirite is concerned, even if all things change, then they change in rational ways in accordance with their natures, i.e. in accordance with the Principle of Identity broadly or rather dialectically understood. Thanks to the distinction between potency and act, for instance, the acorn is an oak tree. With no room for invisible lions, Aristotle will therefore find a way to justify the guide's "A lion!" where we would be inclined to see only circling condors. There is no "idea" in Aristotleexcept, perhaps as usefully immanent in physical things-while the expression "indistinguishable quanta" is perfectly un-Aristotelian in spirit: through Form, otherwise indefinite Matter becomes individualized.

Postponing a critique of Aristotle for another occasion, ${ }^{3}$ one is tempted to assert that the affirmation of this second principle is originally Jewish. Consider, for example, the self-description of the God of Israel (Exodus 3:14): "I am that which I am." If what makes God unique is that God-unlike all other things-really is what $\mathrm{He}$ is, then all other "things" (one is tempted to call them merely "indistinguishable quanta") are precisely not what they are or even appear to be. With a tautology on one side and paraconsistency on the other ("The woman whom you did give to me 
did give to me and I did eat" is Adam's answer to God's straightforward question: "Did you eat?" at Genesis 3:11-12), Israel's "struggle" with God is as inevitable as it is doomed to failure. And when Moses records the fact that the Sun-condition for the possibility of what we call "a day"-was created on the fourth day (Genesis 1:14-19) we have entered into a world most philosophers would probably like to exclude from philosophical consideration; for their sake, I have consented to confine such questions to "the history of religious paraconsistency." In this world, Hinduism, where Brahm is both everything and nothing, could play the role of Heraclitus to Judaism's Parmenides. So let us-entirely artificially, in my view-confine ourselves to what I have chosen to call "philosophical paraconsistency."

The prehistory of philosophical paraconsistency begins, then, with Parmenides' response to Heraclitus. Only Being is. "The Way of Truth" is an account of Being, i.e. of the truth, and not an account of all those things-the sun and the moon, for instance-that merely appear to be. In short: a radical disjunction between "all things" and that of which we can speak the Absolute Truth has been introduced. Whether or not the Hebrews first recognized this disjunction, Plato was the first philosopher to systematize it. "What is just?" "Justice." Until glimpsed by the traveler, the only marker of the Absolute Truth is tautology: Plato's Being is that alone which is; on the other side of the Truth is the realm of Heraclitean paraconsistency. One might well ask whether Einstein spoke as a Platonist or as a Jew in his 1921 "Geometry and Experience" (Einstein 1983: 28-9):

As far as the laws of mathematics refer to reality, they are not certain; and as far as they are certain, they do not refer to reality. It seems to me that complete clearness as to this state of things first became common property through that new departure in mathematics which is known by the name of mathematical logic or "Axiomatics." The progress achieved by axiomatics consists in its having neatly separated the logical-formal from its objective or intuitive content ...

In fact, this separation had been achieved long ago: it is implicit in Parmenides and explicit—as a matter of "axiomatics" no less—in the Divided Line of Plato.

3. If we wish to teach the Absolute Truth, we would be well advised to defend its opposite with deliberate paraconsistency.

This principle is the theoretical foundation of Plato's deliberate pedagogical paraconsistency in his Republic described above. Here I would point out that its prehistorical origin is found in Parmenides' "The Way of Opinion." Attached to the "The Way of Truth," the goddess also reveals a fraudulent account of all things (DielsKranz, fragment 8.51-52) based on the blending of opposites (DK 8.53-59). It is here that "the cosmology of Parmenides" (e.g. DK fragment 14) is to be found and 
Aristotle duly failed to distinguish "The Way of Opinion" from Parmenides himself (Metaphysics I 986b30-987a2). In fact, it is only comparatively recently that the dialectical purpose of "The Way of Opinion" has once again become visible. A few quotations from the secondary literature will be helpful, the first from G. E. L. Owen (1960: 89):

The goddess, we can now say, is not inconsistent in her denunciation of the mortal opinions she surveys; there is, after all, no saving clause. Her account of those opinions is not introduced as a contribution to early science. But to say this is not to deny that it was the most complete and plausible system its author knew how to produce. If the building of such a system was never his end, it could certainly be a means to his end; and for my part I take its purpose to be wholly dialectical.

More useful is A.A. Long (1963: 106):

On this interpretation the cosmogony, by showing that Parmenides can beat the scientists at their own game, is chiefly useful for the negative purpose of confirming the Way of Truth as the only possible account of reality.

Finally, there is the pioneering contribution of Alexander P. D. Mourelatos (1970: 260):

The primary contribution of the analysis in this chapter [sc. the last chapter is called "Deceptive Words"] is, of course, to the old question of the relation between "Truth" and "Doxa." Why did Parmenides bother, after the proofs of B8, to append an exposition of "mortal opinions" that was actually longer than the first part? He did it as a study in self-deception, indecisiveness, and confusion.

In fact, Parmenides "did it" for a pedagogical purpose: students would be confirmed in the Truth by being exposed to a deliberately paraconsistent account that contradicted its merely tautological essence.

Plato develops this Parmenidean pedagogy to an amazing but much misunderstood extent. Just as Parmenides placed his "The Way of Opinion" after revealing "The Way of Truth," so also Plato placed his cosmological Timaeus directly after the Republic: where the paraconsistent "facts" of the phenomenal world are concerned, nothing more than "a likely story" is possible (cf. Timaeus 29c-d and Parmenides, DK 8.60) This process reaches a negative high point with Plato's Eleatic Stranger, the patricide who asserts that non-Being in some sense is (Sophist 241d). It is not so much that the Stranger's arguments are illogical—they will become the basis for much of Aristotle's well behaved logical system - it is merely the fact that they negate the Parmenidean sense of the verb "to be." Despite appearances-the Eleatic Stranger is customarily identified with Plato-Plato follows Parmenides in asserting

Principia 14(1): 1-14 (2010). 
that only Being truly is (Republic V 478a; cf. VII 521c). He indicates the presence of the lion in full knowledge of the fact that he knows that travelers must see its invisibility-must count, as it were, its indistinguishable quanta-for themselves. As Long (1963, p. 103-4n5) points out: “The difference between Parmenides' approach and that of the Sophist is fundamental; Parmenides is not conceding quasi-validity to the sensible world; he merely shows the principles which would necessarily be assumed of it were valid." Those principles, especially the claim that non-being in some sense is, are paraconsistent.

The prehistory of philosophic paraconsistency is therefore the study not of things but of discourses about things. The paraconsistency inherent in the things of this world, i.e. the validity of the Heraclitean insight, is simply assumed, explicitly by Plato's Socrates (Republic V478d-e) and implicitly by Parmenides' "Way of Opinion." But paraconsistency is not all pervasive: there is always also "The Way of Truth." Prehistoric paraconsistency is therefore merely a means to the truth. To be sure it flatly contradicts our own opinions, it turns the world as we know it upside down, but it is true and above all perfectly self-consistent: it truly is what it is. But precisely because it is not of this visible world, the student cannot simply be shown it. It must be indicated by the flight of condors; only a deliberate self-contradiction reveals the lion's presence.

4. If we wish to teach that the Absolute Truth does not exist, we immediately fall into involuntary paraconsistency.

Throughout his dialogues, Plato's student Cicero grounds his skepticism on the example of Socrates: he knows that he knows nothing (scire se nihil se scire). Every careful reader of Plato knows - and no one read Plato more carefully than Cicerothat Socrates never actually says this: what Socrates claims is that he alone does not think that he knows the things that he does not know (Apology 21d5-6). It was, in fact, the greatly underestimated Cicero who created the self-contradictory Socrates or at least he gives "knowledge of ignorance" its first literary expression (Academica II.74 is quoted above; cf. I.16 and I.45). For this reason, Cicero really belongs in the previous section: he continues the Parmenidean tradition of deliberate pedagogical paraconsistency that he learned from Plato (see Glucker 1978, p. 296-8). But in a religious world where the invisible lion became a dogma, philosophers were willing to grasp at straws and many took Cicero's merely pedagogical skepticism-he was really trying to lead his students to Plato's invisible truth (Orator 10-12) —at face value. "There is no Absolute Truth" is the culmination of this anti-theological "wisdom." Of course it cannot possibly be true that there is no truth: if there were no truth, it would be impossible to claim that "There is no Absolute Truth" is true. We must therefore believe that "Everything is a Matter of Opinion" is not itself an opin-

Principia 14(1): 1-14 (2010). 
ion and that we can know with absolute assurance that "Nobody knows the Absolute Truth."

5. If we wish to assert more about the otherworldly Absolute Truth than its inspiring existence, we will immediately fall into involuntary paraconsistency.

This principle is embodied in Kant. The noumenal realm exists and the Ding an sich can inspire ethical action but the Antinomies await those who neglect the limits of reason. Kant is therefore best understood as a Platonist.

6. If we wish to assert the Absolute Truth about all things, we must affirm the Absolute Truth of paraconsistency.

This principle is embodied in Hegel. "Limits of Reason" is the mere figment of Kant's one-sided Understanding (Verstand): reason (Vernunft) can conceptualize the Whole. But the one-sided or paraconsistent moments of Verstand-of which Kant's four Antinomies are only the beginning-are an essential part of Venunft: self-contradiction is inherent in all that is actual. This principle-a philosophical expression of Hinduism - is probably the beginning of philosophical paraconsistency's History; certainly da Costa has already discussed Hegel (da Costa 1980; Chapter 3). The critical difference between historical paraconsistency and its Platonic prehistory is visible in Hegel: Hegel argues that paraconsistency is inherent in things whereas in the mere prehistory of paraconsistency, paraconsistency is that in accordance with which a fraudulent discourse about those things is to be constructed. This is not to deny that Hegel is reviving Heraclitus or that Heraclitus was also the provocation for Platonic or rather Parmenidean paraconsistency. By following rather than absorbing Heraclitus, Hegel is systematizing the self-contradiction inherent in the claim that "All Things are One." For this reason, Hegel must ultimately fall prey to the first principle no less than Heraclitus did. The involuntary self-contradiction in Hegel turns out to be inherent in Reason's claim to transcend the limits of Understanding by knowing precisely the Whole: the Whole in Hegel, although it contains selfcontradiction within it, is necessarily both limiting and limited while the unlimitedwhether conceived as God, wisdom, or the future-has no place in Hegel's thought. The most accessible of these self-contradictions is the subject of my doctoral dissertation (UFSC): "The Problem of Time in Hegel's Philosophy of History." So further discussion of this topic can conveniently be postponed.

7. If we wish to annihilate the existence of Absolute Truth, we must make a deliberate decision to affirm the Absolute Truth of a self-contradiction.

This principle of militant paraconsistency is embodied in Bergen-Belsen, Auschwitz, and Dachau. Strictly speaking, then, it does not belong to the prehistory 
of philosophical paraconsistency but rather to the extirpation of its Jewish origin or analogue. On the other hand, the boundary between religious and philosophical paraconsistency has already disappeared in Hegel nor was it ever really very well defined, as I suggested earlier. The Nazis prove, indeed, that the distinction is strictly artificial.

Take Nietzsche for example: for all their alleged humility, it is the exact same Will to Power that drives every action and every philosophical or religious system that motivates Judeo-Christians. But if the Will to Power is the basis of every system, including "Blessed are the gentle, for they shall inherit the earth" (Matthew 5:5), it is likewise the basis of Nietzsche's own. That which deconstructs the thinking of others inevitably deconstructs itself. Or does it? The philosophers of National Socialism, with deliberate paraconsistency, will not allow it to do so. Consider also Historicism: if every system of thought is the product of its own time or historical circumstances, none is absolutely true. But if Historicism is applied to itself, then the view that no system transcends its own time or historical circumstances is merely the product of its own time as well. In other words: Historicism can deconstruct Historicism. This view the thinking Nazis will decide to accept. And if the truth of Historicism can negate Historicism, then the self-destruction of the Will to Power need not be given the last word (Strauss 1953: 26): we can DECIDE that the Will to Power does not deconstruct itself: we (so say the Nazis) are the makers of values and there is nothing True unless we decide that it is True. "Truth is our creation: we are the gods of Truth," thus spake Zarathustra in a brown shirt.

It is all very well to assert: "God is Dead." But precisely because the creator God is not of this world, the basis for believing in this God is and always was and will be a matter of faith, not proof. We can ridicule Kant's Ding an sich, we can fool some of the people with "There is No Truth." But the separation of Church and State, while leaving room for Kant's faith, has created a limited Liberal state that stands directly opposed to any one individual's Will to Power. Because the worst excesses of religious dogmatism have been limited and contained by Liberalism's willingness to leave open a completely apolitical place for God, the only way for the Will to Power to triumph over its flabby bourgeois enemies is through the Triumph of the Will: no matter how paraconsistent it may be, religion must be used against religion.

The core of Nazi thought is "Decisionism" (von Krockau 1990): a doctrine is true only because I decide that it is so. But the presence of that "only" requires that the doctrine upon which the decisionist decides cannot be true for any merely conventional reason. Therefore the core of Decisionism is the affirmation of a doctrine that cannot possibly be true in the conventional sense. This is why National Socialism is best understood as a deliberate self-contradiction but hardly a pedagogical one designed to lead the traveler to the truth: it is a Godless faith, a theology without God, an atheistic religion (Altman 2010: 159, 247, and 268). And it is on 
this somber note that I bring my brief "Prehistory of Paraconsistency" to an end; I will leave it to others to search for the link, if any, between this seventh prehistoric principle and paraconsistency's history proper. But I do insist that we must never forget that militant paraconsistency is far more dangerous than an equally false dogmatic consistency and that we must therefore carefully supervise the Platonic-or Jewish-distinction between that which eternally is what it is and everything else that are something rather different although exactly what they are or even if they is remains eternally unclear.

\section{References}

Altman, W. 2010. The German Stranger: Leo Strauss and National Socialism. Lanham: Lexington.

da Costa, N. 1980. Ensaio sobre os fundamentos da lógica. São Paulo: Hucitec. da Costa, N. and Wolf, R. 1980. Studies in Paraconsistent Logic I: The Dialectical Principle of the Unity of Opposites. Philosophia 9: 189-217.

Einstein, A. 1983. Sidelights on Relativity. New York.

French, S. and Krause, D. 2006. Identity in Physics: A Historical, Philosophical, and Formal Analysis. Oxford: Clarendon Press.

Glucker, J. 1978. Antiochus and the Late Academy. Göttingen: Vandenhoeck \& Ruprecht.

Krause, D. 2000. Remarks on Quantum Ontology. Synthese 125: 155-67.

von Krockow, C. 1990. Die Entscheidung; Eine Untersuchung über Ernst Jünger, Carl Schmitt, Martin Heidegger. Frankfurt: Campus Verlag.

Kyburg, H. 1998. Review of 'On the Theory of Inconsistent Formal Systems' et al. Journal of Symbolic Logic 63: 1183-4.

Long, A. A. 1963. The Principles of Parmenides' Cosmology. Phronesis 8: 90-107.

Mourelatos, A. 1970. The Route of Parmenides. New Haven: Yale University Press.

Owen, G. 1960. Eleatic Questions. Classical Quarterly (n.s.) 10: 84-102.

Strauss, L. 1953. Natural Right and History. Chicago: University of Chicago Press.

William H. F. Altman

Departamento de Filosofia

Universidade Federal de Santa Catarina

Campus Universitário, Trindade

88040-900 Florianópolis, SC

BRASIL

whfaltman@gmail.com

Resumo. Celebrando o papel de Newton da Costa na história da paraconsistência, este trabalho examina o uso e abuso da deliberada auto-contradição. Iniciado por Parmênides, desenvolvido por Platão, e continuado por Cícero, uma antiga tradição filosófica usava deliberadamente discursos paraconsistentes para revelar a verdade. Nos tempos modernos, o decisionismo tem usado uma deliberada auto-contradição contra a revelação Judaico-Cristã.

Palavras-chave: Paraconsistência, Parmênides, Platão, Cícero, decisionismo, Leo Strauss.

Principia 14(1): 1-14 (2010). 


\section{Notes}

${ }^{1}$ Republic VI 510b10-d3: "Well, I will try again," said I, "for you will better understand after this preamble. For I think you are aware that students of geometry and reckoning and such subjects first postulate the odd and the even and the various figures and three kinds of angles and other things akin to these in each branch of science, regard them as known, and treating them as absolute assumptions, do not deign to render any further account of them to themselves or others, taking it for granted that they are obvious to everybody. They take their start from these, and pursuing the inquiry from this point on consistently, conclude with that for the investigation of which they set out."

${ }^{2}$ I am grateful to Décio Krause for his helpful suggestions-including the distinction made here-particularly in the light of his extremely gracious response to my deliberate obfuscation of his intentions in using the word "idea." Naturally I do not mean to indicate his endorsement of the errors that remain here.

${ }^{3}$ In an article under review called "Why Plato's Idea of the Good is not the One," I claim that Aristotle's discussion of the One and the Indefinite Dyad in Metaphysics $\mathrm{M}$ and $\mathrm{N}$ is more useful for understanding Aristotelian Matter and Form than Plato's late theory of Ideas; this suggests that the ontological priority of the "individual" depends on the self-contradictory notion that there is an indefinite plurality of ones each of which is an indefinite plurality made one.

Principia 14(1): 1-14 (2010). 